\title{
Organizational-level interventions in small and medium-sized enterprises: Enabling and inhibiting factors in the PoWRS program
}

Ipsen, Christine; Gish, Liv; Poulsen, Signe

Published in:

Safety Science

Link to article, DOI:

10.1016/j.ssci.2014.07.017

Publication date:

2015

Document Version

Peer reviewed version

Link back to DTU Orbit

Citation (APA):

Ipsen, C., Gish, L., \& Poulsen, S. (2015). Organizational-level interventions in small and medium-sized enterprises: Enabling and inhibiting factors in the PoWRS program. Safety Science, 71(Part C), 264-274. https://doi.org/10.1016/j.ssci.2014.07.017

\section{General rights}

Copyright and moral rights for the publications made accessible in the public portal are retained by the authors and/or other copyright owners and it is a condition of accessing publications that users recognise and abide by the legal requirements associated with these rights.

- Users may download and print one copy of any publication from the public portal for the purpose of private study or research.

- You may not further distribute the material or use it for any profit-making activity or commercial gain

- You may freely distribute the URL identifying the publication in the public portal 


\title{
Multi-level stress management interventions in SMEs - Experiences with the PoWRS model
}

\author{
Ipsen, Christine, Associate Professor, $\mathrm{PhD}$ \\ Technical University of Denmark \\ Department of Management Engineering \\ Work System Design \\ chip@dtu.dk
}

\author{
Gish, Liv, Post. Doc., PhD \\ Technical University of Denmark \\ Department of Management Engineering \\ Work System Design \\ ligi@dtu.dk \\ Signe Poulsen, Post. Doc., PhD \\ Technical University of Denmark \\ Department of Management Engineering \\ Work System Design \\ sipo@dtu.dk
}

Keywords: primary interventions, SMEs, organizational change, participatory action research, case study. 


\begin{abstract}
Work-related stress in SMEs is an increasing problem. However, knowledge regarding stress management interventions in SMEs is limited. Often SMEs lack professional in-house facilitator resources to assist change processes. The aim of this paper is to describe the outcomes of four SMEs applying a participatory multi-level intervention model known as "PoWRS" and identify enablers and barriers related to the intervention. The companies' outcomes regard the specific intervention, influence on productivity and well-being, and unexpected outcomes. Main enabling factors included multi-level engagement in reflections, decision making and implementation of the changes through all phases, local untrained facilitators assisting the process, active line managers and senior management, continuous evaluations and adjustments and visualization of the progress.

Some of the critical barriers were lack of process experience, imbalance between operations and development, and lack of management support. Implications of the findings for work-related stress preventions in SME using the model are discussed.
\end{abstract}




\section{Introduction}

Knowledge intensive SMEs in Denmark experience increasing problems with work-related strain and stress and today work-related stress is considered to be just as hazarding as accidents at the workplace (European Agency for Safety and Health at Work, 2010).

Several tools and methods to alleviate work-related stress are accessible for SMEs through unions and public websites. This could be stress coaching or stress courses. A common feature of these tools and methods is that they primarily target individuals and are secondary or tertiary interventions e.g. how employees can alleviate the challenges they face in their work, or how employees can be trained to cope with these challenges. Current tools and methods with a preventive aim often require the cooperation of an external consultant in the implementation of a new practice.

While SMEs have recognized the need for change and have access to tools and methods, only few of the SMEs have access to in-house consultants who can apply these tools and initiate and facilitate primary stress management interventions. In large companies such resources and competences can be found in HR, but not in SMEs. Furthermore it has not previously been a task for safety advisors to facilitate interventions, so SMEs can seldom find help here either. SMEs are thus uncertain about how to approach primary stress interventions and initiate relevant change processes (European Agency for Safety and Health at Work, 2010; Nielsen, Grex, \& Jørgensen, 2010).

There is therefore a need for knowledge on how SMEs can initiate and implement primary interventions (Kompier \& Kristensen, 2000; Murphy, 1988) and address the underlying organizational conditions that can lead to work-related stress (European Agency for Safety and Health at Work, 2010; Nielsen, Raymond, Holten, \& González, 2010; Randall, Cox, \& Griffiths, 2007).

Mellor et al. (2011), point at a significant body of research which has shown a link between work characteristics and employee stress and wellbeing. Others find that when conducting stress preventive actions through organizational development, it is important to understand the relation between the sources of work-related problems and the organizational design of the workplace (Dettinger \& Smith, 2006; Smith \& Sainfort, 1989). A participatory intervention model, known as the PoWRS model (Prevention of Work Related Stress) (Andersen \& Ipsen, 2010) embraces both the link between work characteristics, employee stress and wellbeing. It also covers the relation between the sources of work-related problems and the organizational design of the workplace. 
Thus, the PoWRS model differs from other stress prevention intervention models because it focuses on changing both the organization and work characteristics and practices that cause work-related stress. The PoWRS model does this by prescribing a multi-level participatory intervention involving in-house resources. The in-house facilitators are involved to explicate tacit knowledge, decide collectively on changes to be implemented, and facilitate the activities in a collective process. Since the PoWRS model has been developed for large companies it has been the overall aim of our research project to customize it and make it applicable in a SME context.

In this paper we want to investigate the PoWRS models applicability in SMEs, particularly enablers and barriers in relation to what makes the model work in SMEs. Further, special attention is given to the perceived results for the case companies. The purpose of this paper is therefore to answer the following research questions:

What are the enablers and barriers when applying the PoWRS model in SMEs?

What changes do the case companies experience as a result of implementing the PoWRS model?

The research questions have been answered using a mixed-methods case study (Johnson \& Onwuegbuzie, 2004; Robson, 2002; Yin, 1989) involving four Danish SMEs.

The paper is structured as follows. In the following section, we review the literature on interventions of interest to this study. Next, we describe the case research method applied in the current study. Then, we present results of the data analyses. A discussion of our findings in the light of enablers and barriers in the model follows. The paper concludes with a summary of the main findings, the implications for research and practice, as well as the limitations.

\section{Theoretical background: customizing the PoWRS model}

In a previous research project called "Knowledge Work and Stress" a long-term intervention model was developed and applied in six larger Danish knowledge intensive companies (Andersen \& Ipsen, 2010; Ipsen \& Andersen, 2011; Sørensen \& Holman, 2010). The model was labeled the PoWRS model and aimed at developing organizational-level changes and secure sustainability. The aim of the research project was to gain knowledge about how large Danish knowledge intensive companies can develop strategies and implement stress preventive initiatives in a participatory process (Buch \& Andersen, 2008; Buch, Andersen, \& Sథrensen, 2009; Ipsen \& Jensen, 2012; Ipsen \& Andersen, 2013). 
The PoWRS model concerns primary interventions i.e. re-designing work processes and daily activities, and applies a participatory approach in interventions and as part of the evaluations (Greene, 1997; Hurrell \& Murphy, 1996; Ipsen, Jensen, \& Andersen, 2010; Murphy, 1988; Murphy \& Sauter, 2003; Rosskam, 2009). In the development of the model's design and content, the discussions regarding determinants in primary preventive interventions were also taken into account as well as how the intervention process and the effects can be understood. (Cox, Karanika, Griffiths, \& Houdmont, 2007; Nielsen, Fredslund, Christensen, \& Albertsen, 2006; Nielsen et al., 2010; Randall, Griffiths, \& Cox, 2005)

The PoWRS model comprise a long-term process in three phases: First an assessment of the need for intervention is conducted, next a set of activities to decide the kind of intervention is conducted, and finally the intervention is implemented and continually evaluated. A more detailed description of the model is presented in the next section. The core idea of the model is that managers and employees together focus on the work conditions of the employees, e.g. what conditions excites and what stresses. Subsequently they also initiate organizational-level changes together (Hurrell \& Murphy, 1996; Murphy, 1988).

The intervention takes place in a dynamic development process inspired from "Design Thinking” (Brown, 2008; Simon, 1981), which is a practical and creative process of creating ideas through cooperation, systems understanding, visualization, testing and adjustment. The process requires shared reflections between managers, employees as well as other relevant stakeholders (Randall et al., 2007) where tacit knowledge about causes and solutions to work-related problems become explicit. This creates a basis for sustaining preventive solutions (Kompier et al., 1998; Nonaka \& Teece, 2002). The underlying premises of the model are listed in the following:

1. Multi-level collaborative approach from both managers and employees

2. Active support from managers for example the project is given equal status with other daily activities and changes.

3. Explication of tacit knowledge among employees and managers regarding work-related problems and potential solutions

4. Clear goals are set, which can be evaluated continuously based on collective evaluations and adjusted

5. Visualization of the process and results to promote awareness and commitment

6. Appointment of one facilitator for each intervention to be the "ears of the organization"

7. A development project with a set project period 
The "Knowledge Work and Stress" project confirmed that these premises are of key importance for supporting the re-design of the work processes in a multi-level, participatory process (Buch \& Andersen, 2009a; Ipsen \& Andersen, 2013; Sørensen \& Holman, 2010).

Applying the model in larger knowledge intensive companies gave rise to organizational and managerial changes. The case studies have shown good results for example improved well-being, more responsibility among employees, increased well-being, new leadership practices, and organizational capabilities and competences (Buch \& Andersen, 2009b; Ipsen, 2011; Ipsen \& Andersen, 2013; Sørensen \& Holman, 2010)

A key finding was that the process has to be supported by actors who have access to and can facilitate processes and apply relevant methods and create awareness of the process. In contrast to large companies SMEs often experience that they do not have access to in-house consultants who have these capabilities. However, they experience similar problems with work related stress and express a need for a model on how to take action. In addition, there is also a need for "frame models” where the SMEs can adjust the content to the local practice (Mellor et al., 2011). As the PoWRS model is a specified framework where the content of the intervention is to be adapted to the local context, so the changes fulfill the specific needs, it corresponds with the SMEs requests. By building on a participatory and multi-level principle it also ensures a requested strong voice for employees (Editorial, 2011).

In the present research project the customization of the PoWRS model has entailed that local, untrained in-house actors are going to facilitate the intervention. This is done by facilitating the different process activities, listening to their colleagues during the interventions, and present their results and conclusions to colleagues and managers. But otherwise, the intervention design and the underlying principles are the same as in the "Knowledge Work and Stress” project.

\section{The PoWRS tool - The intervention model}

The PoWRS model comprises three phases and a set of activities in which both employees and managers participate step by step in order to explore their workplace. In collaboration, they evaluate and re-design their work practices, organizational design and implement change (Andersen \& Ipsen, 2010; Ipsen \& Jensen, 2012; Ipsen \& Andersen, 2013; Sørensen \& Holman, 2010).

Phase 1 comprises assessing the need for a primary intervention. Startup considerations require that senior management commit to support the approach and allocate resources for the intervention. 
Setting up a project group is also done at this point. The group is constituted with three to five members. One member should be a manager, who acts as project manager. Two of the other members are employees who act as local in-house facilitators. Other persons who could be of particular importance of the process should also be involved. The in-house facilitators are employees who will have the role as the “organization's ears”. They help to ensure that everyone is continuously involved and listened to during the intervention.

Phase 2 involves exploring the work and workplace by conducting two FishBone workshops (Sørensen, 2010) inspired by Ishikawa (Ishikawa, 1968). First, in their own workshop the employees map their experiences in relation to their work practices and conditions by answering two questions: "What excites you in your work?" and "What create stress and strain you in your work?" The answers are posted on two charts illustrated with a FishBone each labeled "Enthusiasm” and "Strain”. When all participants have presented their post-it notes, two images emerge of the factors that create enthusiasm and stress at this particular workplace. A corresponding workshop is carried out among line- and team manages where employees do not participate. However, focus is still on the employees, their working life and how it is perceived by the managers. Immediately following the FishBone workshops, a "Multi-Voting” session (Gray, Brown, \& Macanufo, 2010; Jungk \& Müllert, 1981) is initiated. In this session both managers and employees vote for the work conditions they prefer to change in the following months. The outcome of the session is a five topics list of the work conditions that should be prioritized.

Hereafter follows a period of time where everyone is interviewed by the two facilitators. The aim of the interviews is to clarify expectations, meaning of the priorities and generate ideas for supporting activities. The data make the project group able to select the two most important issues to focus on in the intervention. When top two are selected the launch is marked with a Kick-Off event. The aim of the Kick-Off event is to highlight the start of the change process regarding the top two organizational-level changes.

Phase 3 concerns the implementation of the organizational-level changes and continuous evaluations and adjustments. The changes are now implemented during the next months. The department accomplishes this by systematically investigating, initiating and implementing the chosen changes. It is of key importance in order to secure primary preventive changes that all members participate in the intervention and that the changes are integrated into existing activities at the workplace. This integration can occur in connection with department meetings, project start-ups and task planning, to name a few examples. 
At this point, it is the responsibility of the project group and facilitators to initiate activities that can ensure momentum, with the overall aim to ensure that the intervention succeeds. The project group meets regularly during the project to evaluate the process and results. The group typically presents their observations and conclusions at departmental meetings, followed by a discussion with the rest of the department.

By working with changes over a longer period, there is opportunity for ongoing reflections, improvement and adjustment of these, and thereby ensure that the changes are embedded in the company and in the daily activities (Dahler-Larsen, 2001; Murphy, 1988; Newell, 2002).

The project team is responsible for driving the process and ensures that the project goes according to plan. In this process, the employees play an important role in cooperation with the project team. The result of the intervention is a collective process in which a number of preventive strategies and interventions are initiated and implemented.

To make certain that a sharp focus is maintained on the project, it is recommended that the companies continually focus on clarifying and make the targets and process visible by visualizing both (Gray et al., 2010; Rasmussen, 2008; Womack, Jones, \& Roos, 2007) An example of this is providing each employee with a red and green ball and once a week let them vote on progress by putting a ball in a tube. The tube should be placed centrally on the worksite. If the participants have perceived progress they put the green ball in the tube and a red ball if they think have the opposite experience.

\section{Methodology}

The research project is an explorative case study of four SMEs which each have conducted a six months intervention process applying the outlined intervention model. To collect data we have used a mixed method approach (Johnson \& Onwuegbuzie, 2004; Johnson, Onwuegbuzie, \& Turner, 2007) including observations, interviews, surveys and Chronicle Workshops.

\subsection{Case companies}

The case companies were identified and recruited through the researchers' own network, Linked-In, advertisement in branch magazines, and direct enquiry by phone. Four Danish SMEs were finally selected to make up the sample and they all agreed to participate actively in the project. Two of the companies are IT-companies and two of them are manufacturing companies, ranging from 31 to 187 employees. Table 1 shows an overview of the overall size of the case companies, the 
number of participating departments in the companies and the number of participants in the intervention. Due to its small size Company 1 chose that the whole company should participate. In the rest of the case companies only two to three selected departments.

\begin{tabular}{|l|c|c|c|c|}
\hline & Company 1 & Company 2 & Company 3 & Company 4 \\
\hline $\begin{array}{l}\text { Company size (overall number of } \\
\text { employees) }\end{array}$ & 31 & 116 & 150 & 36 \\
\hline $\begin{array}{l}\text { Number of participants in the } \\
\text { intervention }\end{array}$ & 31 & 25 & 37 & 2 \\
\hline $\begin{array}{l}\text { Number of participating } \\
\text { departments }\end{array}$ & 2 & 2 & 3 & 2 \\
\hline
\end{tabular}

Table 1. Size of the participating companies and number of participants

\subsection{Data collection}

The research team followed the intervention process in all of the four companies by observing the planned activities and progression of the interventions at onsite visits. Observations were documented through handwritten notes. Furthermore project managers, in-house facilitators, employees and other relevant stakeholders were interviewed during the process, and three rounds of surveys were answered by the intervention participants. In all 53 interviews were conducted, lasting from 19 minutes to 70 minutes. Each interview was audio recorded and then transcribed. At the end of the intervention, each company intervention was evaluated by a number of employees in a Chronicle Workshop (Rasmussen, 2011). In the Chronicle Workshop three rounds of questions were asked: 1) Which important changes have occurred during the last six months that have affected your work?, 2) which important changes in your work have you discovered in relation to the two interventions?, and 3) which factors have impacted the interventions? An overview of the data collection activities are shown in Table 2.

\begin{tabular}{|l|c|c|c|c|}
\hline & Company 1 & Company 2 & Company 3 & Company $\mathbf{4}$ \\
\hline FishBone survey & 22 respondents & 22 respondents & 28 respondents & 31 respondents \\
\hline Kick-Off survey & 15 respondents & N/A & 21 respondents & 24 respondents \\
\hline Kick-Off interview & 3 interviews & 3 interviews & 3 interviews & 4 interviews \\
\hline First follow up interview & 5 interviews & 5 interviews & 5 interviews & 4 interviews \\
\hline
\end{tabular}




\begin{tabular}{|l|c|c|c|c|}
\hline Second follow up interview & 5 interviews & 4 interviews & 4 interviews & 5 interviews \\
\hline Chronicle Workshop & 6 participants & N/A & 4 participants & 5 participants \\
\hline Completion interview & 1 interview & N/A & 1 interview & 1 interview \\
\hline Completion survey & 22 respondents & N/A & 30 respondents & 22 respondents \\
\hline
\end{tabular}

Table 2. Overview of data collection activities

All four companies completed the first and the second phase of the PoWRS model. Company 2, however, had a hard time to implement the selected intervention in the third phase. After conducting the FishBone workshop they postponed the intervention for three weeks. Furthermore Company 2 did not answer the Kick-off survey and cancelled the Chronicle Workshop. Due to the initial delay of the intervention and other problems in the implementation, the completion interview has not yet been answered. Yet, we argue that insights from Company 2 cannot be dismissed because this case especially points to the barriers for implementing interventions. The other three companies did complete the third phase of the model.

The research team did not participate in corporate daily activities or the daily implementation of the interventions. However, we did act as sparring partners for the company project groups. E.g. help with interview guides and techniques. Whenever the project groups have needed sparring or further input we have used this as information on how to further improve the PoWRS model and make activities and tools easier to understand.

\subsection{Data analysis}

The aim of the following analysis was twofold: (a) to identify what makes the PoWRS model applicable in SMEs i.e. enablers and barriers for conducting an intervention in SMEs and, (b) to identify what the company participants perceive as results of the intervention

Both the Chronicle Workshop and interview data were analyzed using a qualitative analysis method (Miles \& Huberman, 1994). Our analysis focused on employees as the primary stakeholder group as they comprise the core of the work processes and are those who may experience workrelated stress and problems. First data from the Chronicle Workshops were coded. This was done to develop an understanding of meaning and patterns in the data across the cases regarding the enablers and barriers of the intervention and the results from the intervention. Next, the interview transcriptions were coded using NVivo. This was done to provide a richer meaning to the outcome of the Chronicle Workshops. Interviews were coded for both enablers and barriers of the 
intervention, and perceived results by the companies. Finally, the three surveys were used to validate the qualitative data. They provided data in a standardized form from a larger number of individuals and could indicate how widespread the phenomenon in question is (Robson, 2002).

\section{Findings}

In the following we first report on the actual implementation of the PoWRS model in the four companies and what have been found as enablers and barriers for implementing the model in SMEs. Next we present what managers and employees in the case companies perceive as the results of using the PoWRS model.

\subsection{Implementation of the PoWRS model}

Data show that in the first phase of the PoWRS model it was relatively easy for the managers in the four SMEs to identify the in-house facilitators based on facilitators had to be trusted by their colleagues. One manager explained the following about one of the in-house facilitators: "He is respected, because he has been here for so long. People know what he stands for and they know that he has been on shorter hours for a period of time because of a stressed situation. [...] So in that way people know he has a concrete experience with high work pressures. To me, that is what makes [Facilitator 1] the right person.”

In the second phase, the FishBone workshop acted as an eye opener to both employees and managers as they got more insight into which working conditions that create enthusiasm and strain at their work place. One manager formulated it like this: "The fact that we focus on it now will be an eye opener for everybody, I definitely think". The interviews and the Chronicle Workshops showed that the FishBone also formed a strong reference point through the rest of the interventions.

The specific outcome of the FishBone workshops and the subsequent Multi-Voting session are presented in table 3. 


\begin{tabular}{|l|l|l|l|l|}
\hline$\underline{\text { Change 1 }}$ & \multicolumn{1}{|c|}{ Company 1 } & \multicolumn{1}{c|}{ Company 2 } & \multicolumn{1}{c|}{ Company 3 } & \multicolumn{1}{c|}{ Company 4 } \\
management & Worn tools and machines & $\begin{array}{l}\text { Collegiate spirit, unity } \\
\text { and feedback }\end{array}$ & $\begin{array}{l}\text { Polite tone and less } \\
\text { gossip }\end{array}$ \\
\hline$\underline{\text { Change 2 }}$ & Time and tasks & $\begin{array}{l}\text { Improved quality: } \\
\text { Error-free subjects and } \\
\text { components }\end{array}$ & Well defined tasks & $\begin{array}{l}\text { More cooperation and } \\
\text { team spirit }\end{array}$ \\
\hline$\underline{\text { Change 3 }}$ & $\begin{array}{l}\text { Better management and } \\
\text { communication }\end{array}$ & $\begin{array}{l}\text { Good flow and better } \\
\text { planning }\end{array}$ & Equipment that works & Consistent quality policy \\
\hline$\underline{\text { Change 4 }}$ & $\begin{array}{l}\text { More recognition and } \\
\text { feedback }\end{array}$ & $\begin{array}{l}\text { Polite tone and less } \\
\text { gossip }\end{array}$ & Feedback & Visible manager \\
\hline $\begin{array}{l}\text { Change 5 } \\
\text { b) Improved international } \\
\text { communications }\end{array}$ & $\begin{array}{l}\text { Improved management: } \\
\text { Recognition and } \\
\text { employee involvement }\end{array}$ & Facilities and noise & Consistent manager \\
\hline
\end{tabular}

Table 3. Overview of top five priorities - outcome of the FishBone and Multi-Voting session

After the FishBone workshop all employees were interviewed by the two in-house facilitators. This clarified the expectations and meaning of the priorities and gave a few suggestions for supporting activities. One in-house facilitator reports: "We made these group interviews and we placed some posters in the canteen so people could write their ideas if they didn't catch us right away, or they suddenly got an idea. We also mounted door hangers on all the doors, just as inspiration. [..]. I think that people generally received it well. That was positive. There were a few that didn't like it - it is the same who always want to see the negative things." Another objective with the interviews was to ensure support for the intervention. As the quote shows most were positive, but some employees did not feel committed. Generally in three of the companies, the participants reported that they were still being consulted and involved in the intervention after the FishBone workshop.

The in-house facilitators' interviews made it possible for the project group to select the two most important issues to focus on in the intervention. However, in all the companies they felt that the two to three weeks that they had for this activity were too little time to make the decision, and in one company they postponed the decision with another three weeks. When the top two priorities were selected the launch was marked at the Kick-Off event where also the supporting activities were presented in three of the companies. See table 4. 


\begin{tabular}{|c|c|c|c|c|}
\hline & Company 1 & Company 2 & Company 3 & Company 4 \\
\hline $\begin{array}{l}\text { Change } 1 \text { with } \\
\text { supporting activities }\end{array}$ & $\begin{array}{ll}\underline{\text { Better project }} \\
\text { management } \\
\\
\text { - } \quad \text { Team meetings } \\
\text { - } \quad \text { Definition } \\
\text { - } \quad \text { Status } \\
\text { - } \quad \text { Insight } \\
\text { - } \quad \text { Kick-Off } \\
\text { - } \quad \text { meetings } \\
\text { - } \quad \text { Right people } \\
\text { - } \quad \text { Quality }\end{array}$ & $\begin{array}{l}\text { Improved quality: } \\
\text { Error-free subjects and } \\
\text { components } \\
\quad \text { No supporting } \\
\text { activities were } \\
\text { specified }\end{array}$ & $\begin{array}{ll}\text { - } & \text { All tasks are } \\
\text { communicated } \\
\text { clearly } \\
\text { - } & \text { Shared } \\
\text { responsibility for } \\
\text { briefing and } \\
\text { debriefing when } \\
\text { tasks are handed } \\
\text { over } \\
\text { Mutual feedback } \\
\text { when tasks are } \\
\text { completed }\end{array}$ & $\begin{array}{l}\frac{\text { Polite tone, less }}{\text { gossip, more }} \\
\text { cooperation and } \\
\text { team spirit } \\
\text { - } \quad \text { Mutual respect } \\
\text { and tolerance } \\
\text { - Talk directly } \\
\text { with each other } \\
\text { - } \quad \text { Rotation in } \\
\text { groups } \\
\text { Make small } \\
\text { team games }\end{array}$ \\
\hline $\begin{array}{l}\text { Change } 2 \text { with } \\
\text { supporting activities }\end{array}$ & $\begin{array}{l}\text { More recognition and } \\
\underline{\text { feedback }} \\
\text { - } \quad \text { Manager } \\
\text { feedback } \\
\text { - Customer } \\
\text { feedback } \\
\text { - Team members' } \\
\text { feedback } \\
\text { Repeated trouble } \\
\text { shooting }\end{array}$ & $\begin{array}{l}\frac{\text { Improved management: }}{\text { Recognition and }} \\
\text { employee involvement } \\
\text { - } \quad \begin{array}{l}\text { No supporting } \\
\text { activities were } \\
\text { specified }\end{array}\end{array}$ & $\begin{array}{l}\text { Collegiate spirit, unity } \\
\text { and feedback } \\
\text { - } \\
\text { - Use your internal } \\
\text { network } \\
\text { Focus on internal } \\
\text { knowledge } \\
\text { sharing } \\
\text { - } \quad \begin{array}{l}\text { Focus on } \\
\text { developing }\end{array} \\
\text { competences } \\
\text { - Improvement of } \\
\text { - } \quad \text { Possence backup } \\
\text { meetings } \\
\text { - Database for } \\
\text { sparring }\end{array}$ & $\begin{array}{l}\text { Visible and } \\
\text { consistent manager } \\
\text { - } \quad \text { "Good morning” } \\
\text { round } \\
\text { - Visible in both } \\
\text { - } \quad \text { departments } \\
\text { - Confual respect } \\
\text { - } \quad \text { Office hours }\end{array}$ \\
\hline
\end{tabular}

Table 4. Results of FishBone and Multi-Voting session

During the third phase, the implementation of the changes was carried out in accordance to the context of each of the four companies, e.g. periods with vacation and layoffs etc. But generally it took about two months before any changes were actively implemented. Visualization helped maintain a focus on the intervention, although employees had constantly to be reminded to use it and evaluate the interventions.

\subsection{Perceived enablers and barriers}

Data obtained through interviews and the Chronicle Workshops indicated that a number of factors affected the use of the PoWRS model and subsequently the outcomes. The result of the analysis is summarized in table 5, presented as two themes: Enablers and Barriers. The results demonstrate that 
there has been several affecting factors, supporting and constraining the process during the application of the PoWRS model in the four companies.

\begin{tabular}{|c|c|c|c|c|}
\hline & Company 1 & Company 2 & Company 3 & Company 4 \\
\hline \multirow[t]{10}{*}{ Enablers } & $\begin{array}{l}\text { Management } \\
\text { prioritization }\end{array}$ & & $\begin{array}{l}\text { Management } \\
\text { prioritization }\end{array}$ & $\begin{array}{l}\text { Management } \\
\text { prioritization }\end{array}$ \\
\hline & & & Visualization object & \\
\hline & $\begin{array}{l}\text { Facilitators } \\
\begin{aligned}-\quad & \text { Persistent } \\
& \text { facilitators }\end{aligned}\end{array}$ & & \begin{tabular}{cl}
\multicolumn{2}{l}{ Facilitators } \\
$\begin{aligned}-\quad & \text { Interviews of } \\
& \text { colleagues }\end{aligned}$
\end{tabular} & $\begin{array}{l}\text { Facilitators } \\
-\quad \text { activities }\end{array}$ \\
\hline & $\begin{array}{l}\text { Commitment from } \\
\text { colleagues }\end{array}$ & & $\begin{array}{l}\text { Commitment from } \\
\text { colleagues }\end{array}$ & $\begin{array}{l}\text { Commitment from } \\
\text { colleagues }\end{array}$ \\
\hline & $\begin{array}{l}\text { Employees take more } \\
\text { responsibility (task and } \\
\text { roles) }\end{array}$ & & & \\
\hline & The project group & & & \\
\hline & $\begin{array}{l}\text { Allocated time and } \\
\text { resources }\end{array}$ & & & \\
\hline & & & External facilitation & \\
\hline & & & & Collective process \\
\hline & & & & $\begin{array}{l}\text { Management } \\
\text { commitment }\end{array}$ \\
\hline \multirow[t]{6}{*}{ Barriers } & $\begin{array}{l}\text { Operational priority } \\
\text { over intention activities }\end{array}$ & & & Daily tasks \\
\hline & Pressure of business & & Pressure of business & \\
\hline & $\begin{array}{l}\text { The time/hour of the } \\
\text { day for the joint } \\
\text { activities }\end{array}$ & & & \\
\hline & & & $\begin{array}{l}\text { Management does not } \\
\text { "walk the talk" }\end{array}$ & Lack of support \\
\hline & & $\begin{array}{l}\text { Uncommitted } \\
\text { participation from } \\
\text { colleagues }\end{array}$ & $\begin{array}{l}\text { Uncommitted } \\
\text { participation from } \\
\text { colleagues }\end{array}$ & \\
\hline & & Shift work & & \\
\hline
\end{tabular}




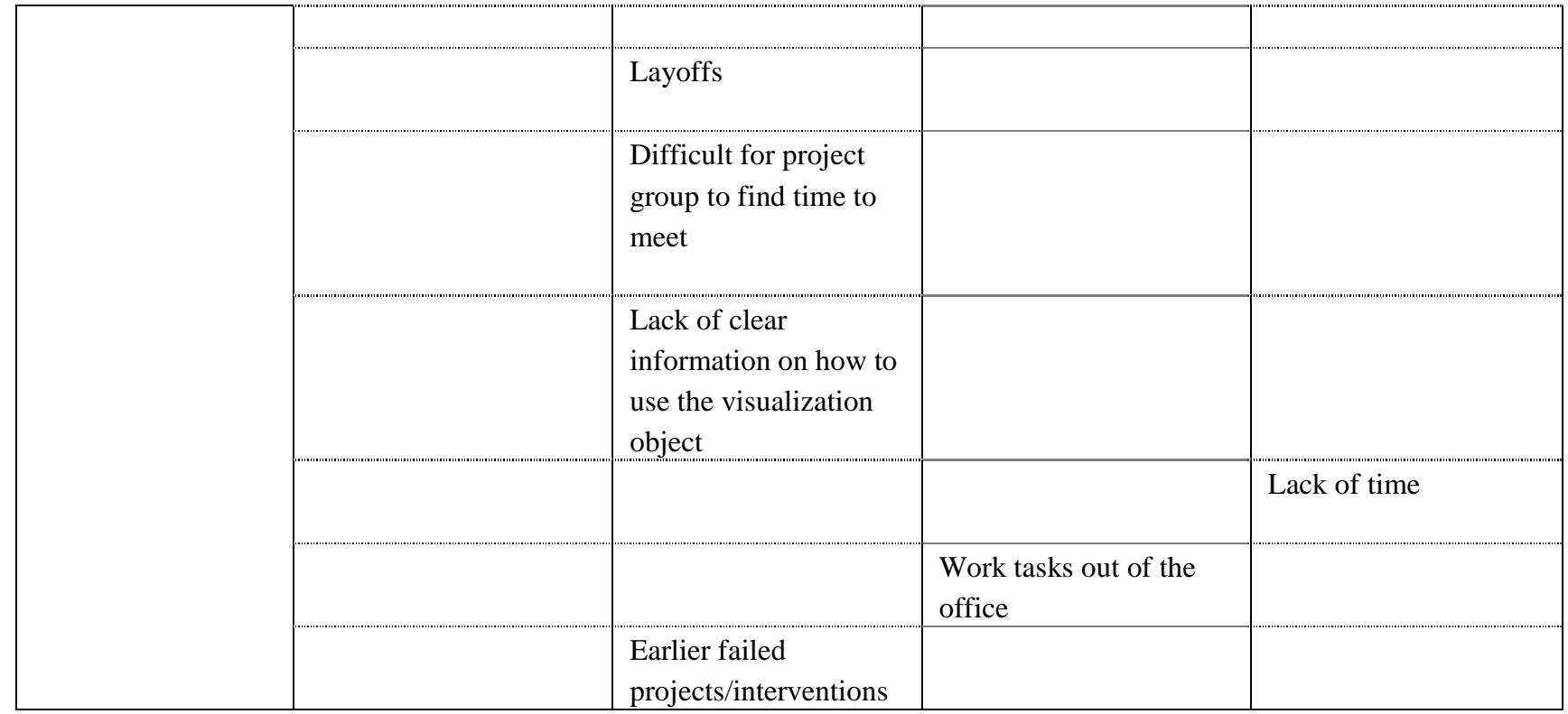

Table 5. Overview of enablers and barriers of implementing the PoWRS model

The qualitative findings are supported by the completion surveys, where the employees are asked to consider which predefined factors or persons that have been helping the process along and which predefined factors or persons that have been a barrier for the process. In all three companies (that have completed the survey) the facilitators are mentioned most often as the most important enablers. It is also found that the fact that it is a joint process is an important enabler. Among the barriers lack of time, the daily tasks, and lack of support are often mentioned.

\subsection{Perceived change of applying the PoWRS model}

Applying the PoWRS model in the four case companies have resulted in different outcomes. Overall the changes can be divided into changes relating to the specific intervention (e.g. project management), overall outcome in relation to productivity and wellbeing, and finally derived outcomes also referred to as "low hanging fruits" by one manager.

With respect to the specific interventions most of the selected changes regard organizational-level changes i.e. focuses on changing work processes whereas a few only focus on individuals i.e. behavior of the individual. The completion surveys show that in Company $1,85 \%$ of the participants think that the changes initiated were the right ones. In Company 3 it is $85.7 \%$ and in Company 4 it is $78.9 \%$. So overall, the majority of the participants acknowledge the selected changes. However, the perceived effect of each change differs a lot across the companies. In table 6 the implemented changes in each company and the participants' perception of the degree of change is presented. 


\begin{tabular}{|c|c|c|c|c|}
\hline & Company 1 & Company 2 & Company 3 & Company 4 \\
\hline $\begin{array}{l}\text { How would you } \\
\text { describe the } \\
\text { change you have } \\
\text { experienced in } \\
\text { relation to } \\
\text { change } 1\end{array}$ & $\begin{array}{l}\underline{\text { Better project }} \\
\underline{\text { management }} \\
\text { Very big change: } 4.5 \% \\
\text { Big change: } 59.1 \% \\
\text { Minor change: } 13.6 \% \\
\text { Small change: } 22.7 \% \\
\text { No change: } 0 \%\end{array}$ & $\begin{array}{l}\text { Improved quality: } \\
\text { Error-free subjects and } \\
\text { components } \\
\text { N/A }\end{array}$ & $\begin{array}{l}\text { Very big change: } 0 \% \\
\text { Big change: } 13.3 \% \\
\text { Minor change: } 30.0 \% \\
\text { Small change: } 20.0 \% \\
\text { No change: } 36,7 \%\end{array}$ & $\begin{array}{l}\underline{\text { Polite tone, less gossip, }} \\
\text { more cooperation and } \\
\text { team spirit } \\
\text { Very big change: } 9.1 \% \\
\text { Big change: } 31.8 \% \\
\text { Minor change: } 27.3 \% \\
\text { Small change: } 22.7 \% \\
\text { No change: } 9.1 \%\end{array}$ \\
\hline $\begin{array}{l}\text { How would you } \\
\text { describe the } \\
\text { change you have } \\
\text { experienced in } \\
\text { relation to } \\
\text { change } 2\end{array}$ & $\begin{array}{l}\text { More recognition and } \\
\text { feedback } \\
\text { Very big change: } 0 \% \\
\text { Big change: } 9.1 \% \\
\text { Minor change: } 54,5 \% \\
\text { Small change: } 18.2 \% \\
\text { No change: } 18.2 \%\end{array}$ & $\begin{array}{l}\text { Improved management: } \\
\text { Recognition and } \\
\text { employee involvement } \\
\text { N/A }\end{array}$ & $\begin{array}{l}\text { Collegiate spirit, unity } \\
\text { and feedback } \\
\text { Very big change: } 3.3 \% \\
\text { Big change: } 13.3 \% \\
\text { Minor change: } 33,3 \% \\
\text { Small change: } 30.0 \% \\
\text { No change: } 20.0 \%\end{array}$ & 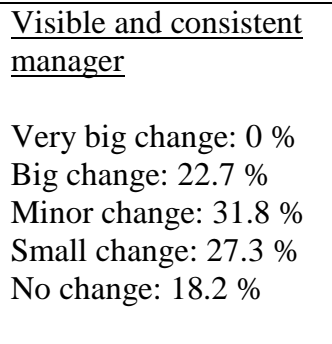 \\
\hline
\end{tabular}

Table 6. Overview of perceived change - results from completion survey

The biggest change is perceived in Company 1 and is ascribed to 'better project management'. In the termination interview the manager from Company 1 also recognized that their development projects now run much better than previously and he believes that it can be attributed the use of the PoWRS model as it "opened their eyes, put words to their problems and helped them structure the change”. In the Chronicle Workshop the employees also recognized a big change regarding project management since new project managers were appointed and project meetings were now held on a regular basis.

In Company 3 especially one department benefitted from the interventions 'well defined tasks' and 'collegiate spirit, unity and feedback', as they experienced a better overview of current projects, more focus on primary tasks and more knowledge sharing. The two other participating departments did not experience the same degree of change. This was revealed in the interviews and Chronicle workshop. In Company 4 each employee performed a personality test in connection with the 'polite tone, less gossip' intervention. This resulted in that some employees now think more about how they talk and how their colleagues might perceive their attitude. Regarding 'Visible and consistent manager' positive change have been recognized by the employees. In Company 4 generally one of the departments was more committed to the intervention than the other. No results have been reported from Company 2.

With respect to overall results concerning productivity and wellbeing the managers in Company 1,3 and 4 expressed that it had been possible to increase productivity while maintaining a high- 
level of wellbeing in the same period. In Company 4 for example the employees were commanded overtime work, five hours per week over a two week period during fall 2012. At the same time an employee satisfaction survey was conducted that showed an increased level of employee satisfaction. Whether or not the individual employee has experienced an increase in productivity and wellbeing varies across the companies, and especially across the different departments within the companies. Especially in the interviews and Chronicle Workshops it became clear that some departments have benefitted more from the intervention than others. Generally, it is easier for the employees to relate to changes regarding the specific interventions than to overall assess whether they experience more wellbeing or feel more productive.

By implementing the PoWRS model some derived changes have also revealed. These were changes or work conditions articulated in the FishBone workshops that were not voted into the top five priorities. However, management found them being “low-hanging fruits” and they became therefore a priority of the company's management, but as an activity outside the intervention. Finally, the PoWRS model was claimed to be a model which the companies would use again. Especially the FishBone workshop was regarded positive as it is easy to conduct. And in a small amount of time it can explicate employees’ and managers’ tacit knowledge.

\section{Discussion}

In our study we applied the customized PoWRS model in four SMEs using local in-house untrained facilitators being merely regular employees undertaking the role. By analyzing data we have seen that the four companies have each changed two of their work-practices during the interventions with a perceived positive effect on productivity and well-being. From the results it is thus apparent that three out of four of the companies have adapted the model to their local conditions with good outcomes.

Although the results divert among the four companies a similarity is noted when the results of the data analysis are considered. We have observed that data point towards that the model's premises and activities are applicable and useful for SMEs.

Our results confirm the usability of the PoWRS model in SMEs and appear to affect the prevention of strain and stress at work by developing and implementing new work practices in a multi-level participatory process using employees as in-house facilitators.

A closer examination of the data shows that it can be categorized in three levels in relation to when affecting the interventions: organizational context, process and content of the model. 
At organizational context level the companies' business context is important for applying the PoWRS model and the implementation of the intervention. In the companies which have a steady flow of tasks, there is more composure to focus on the intervention whereas in the companies with more turbulence and fluctuating tasks it creates insecurity among the employees and a strong focus on the challenges and less on the intervention and the related activities. So even if the management is aiming to meet the listed intervention premises, then the uncertainties mean that there is not enough surplus energy to carry out the intervention.

In line with the participants' descriptions above, we have also observed that the balance between daily operations and intervention related activities has a high impact on the interventions. As listed one of the premises is allocation of resources to the intervention project. This preferably with a project or account number, so that the intervention gets the same status as the daily activities. However, this has not been the case in all companies since it is not existing practice which means that the intervention activities end up competing with daily operations. Therefore applying the PoWRS model requires repeated statements from management that this project is of importance and results are expected. Kompier et al (1998) stresses the importance of support from top management. We would argue that not only top management need to show its support, also middle managers needs to actively support the process.

Geographical and temporal variations have also shown to be a factor affecting the interventions. In companies with shift work, teleworkers or employees working alone on external tasks it has been difficult to make the project a participatory process as it has proven difficult to gather people to the collective activities. SMEs wanting to apply the model should thus be aware of the challenges it creates and that maybe not everyone will be involved despite the intention of being a participatory and multi-level project. It has been argued that employee participation is not crucial in all phases of an intervention (Nielsen et al., 2010) and our results support this.

Finally, we have observed that in the companies which have had previous experiences with change processes ending without results there was resistance to change. Conversely, companies with good experiences of change processes have been able to draw on that experience. The findings suggest that it is essential to bear the story in mind when interventions like these are started, as it can be either a player or opponent.

At process level the PoWRS model has led to concrete work-related changes and new organizational (and individual) capabilities. This study therefore indicates that the benefits gained 
from using the PoWRS model address the local needs and meet the need for an employee voice in change processes (Editorial, 2011).

In line with participants' responses above, the in-house facilitators play a key part as an enabler of the intervention process. By using in-house competences to facilitate the intervention-related activities there is a limited need for bringing in external expertise as has been the case with other models (Mellor et al., 2011). Nielsen et al (2010) point to the fact that it is important when selecting internal facilitators to be very careful in the selection. This is due to the fact that it can be very difficult to be facilitator at your own workplace. Their study does not indicate any specific skills of importance for facilitators, but in the following we will present some of the skills we have found to be crucial for internal facilitators. Data shows that the most important skills the facilitators must have is trustworthiness (Jarret, Kimberly, \& Jianjun, 2009), interest in the specific change and processes (Armenakis, Bedian, \& Niebuhr, 1979). Based on our observation it is also important that the facilitator has a true interest in developing the work-place and not personal interests which he/she would like to see be carried forward. However, despite their central role, their impact seems to be restricted by the organizational context. So even if dedicated facilitators have been appointed their efforts may be made difficult by the organizational challenges. However, as argued elsewhere (Mellor et al., 2011)internal facilitators can help sustain the results of the process.

With regard to the process the PoWRS model activities should be followed steadfast. In cases where project meetings have been skipped or the continuous evaluation has been shattered it has resulted in absent results and decreasing commitment which has also been seen other projects where action plans have not been properly developed and applied (Saksvik, Nytrø, Dahl-Jørgensen, \& Mikkelsen, 2002). The opposite is the case in the companies where the project group has followed the model carefully and conducted all the listed activities and kept the premises in mind. Though they have found it hard at times, they have kept the pace and have had a strong focus which means that everyone has been involved and committed in the process during all the phases. This is in line with the findings of Kompier and colleagues (1998) who find that successful stress prevention requires a systematic approach.

In line with this the data suggests the importance of multi-level participation through all three phases. Both managers and employees state it to be an eye-opener to participate in a collective and multi-level process and express the positive effect it has been to realize that many are dealing with the same challenges but also to start up a collective process where everyone are to participate. However, the collective and participatory approach is challenged in companies with strong 
professional identities and groups. In one company the management team circled around the employees as they voted for their top priorities and in another the employees wanted the voting process to be anonymous due to previous experiences. This shows that it requires special insight and sensitivity from the project group to be aware of trust, groupings and other factors which can affect the process.

Another important thing which is also relevant in this context is the manager's control. Managers from all companies express that being part of a multi-level process secures knowledge and commitment, but at the same time a participatory process with full employee involvement gives them a sense of loss of control. It is thus recommended that managers bear this in mind when boarding the PoWRS model.

Regarding the visualization object it serves the expected purpose in some of the companies. In three of the companies they have adopted the idea of continuous collective evaluations and adjustments of the changes and adapted it to their local context. Consequently, it has taken various forms i.e. wooden blocks on a stick reflecting a bar chart, ribbons in different colors on a board or plastic balls in a tube. The continuous evaluations have secured a focus on the process and made it evident that changes were made with an effect on their work place. However, in some cases it has not been used as intended. At first, all companies have taken the idea to heart. But when the interventions were running there was a tendency to neglect the continuous evaluations and visualization.

The data also shows that process activities with high frequency can be difficult to conduct and integrate into the daily operations. On the other hand respondents state that a high pace secures that focus is kept.

At content level there are no respondents who indicate that there are model components that inhibit the process or do that you cannot get good results. Findings show that the companies have adapted the PoWRS model to fit their local context. The debate revolves around specified models and possibility to tailor “models” to specific needs (Mellor et al., 2011). This is precisely the core of the model as it does not specify which specific changes are to be made at a work-place. Instead it supports tailoring the daily local practice and operations by means of specific activities such as the FishBone workshops, Multi-Voting, continuous collective evaluation, and adjustments of the changes. It thus is thus similar to other organizational-level intervention models (Nielsen et al., 2010). 
The adjustments are tied to the daily practice and the model activities are to be integrated or associated with what is already being done which is the target of the intervention (Murphy, 1988).

The challenges related to the model's content have shown to be in relation to (a) focus on the work practices and not on individuals (b) keeping it a multi-level process (c) definition of the goal and (d) the visualization object.

The challenge for many companies is to focus on the work rather than people (Kompier \& Cooper, 1999; Singer et al., 1986). In one of the companies, this issue is clear as they choose to focus on 'better tone - less gossip' and fails to identify the work context in which this is a problem. It then becomes to be about people's behavior rather than work also known as "Blaiming the Victim” (M. Kompier \& Cooper, 1999)

Another key model component is the collective process that everyone must participate in.

We have observed a strong support for the joint development and decision-making activities, but for some companies it is difficult to make it a collective process when changes must be implemented. This is due to several factors already mentioned, but among other things, lack of management support but also clarity about what the change means for the individual. It is therefore recommended that all participants formulate the concrete changes as accurately so that everyone knows what they should do differently, which can support the multi-level process through all phases.

Defining the goals of the intervention has proven to be a challenge as well. Despite the request to define the expected goal at the start of the process the majority of the managers have had difficulties in formulation of their expectations. This becomes evident during the last interview with the managers. They express a contentment to have applied the model and the results and insights they have gained, but have difficulties in pointing to actual measurable results. It could be stated more clearly in the model that the companies should set goals according the worksites key performance indicators.

Regarding the visualization object some find that it is of less importance and state that it does not make any difference. Others point at the key part it plays in order to secure commitment and focus. The findings overall suggest that it is an activity to be carried out even if it can seem to be of less importance. Finally, it is a challenge to be loyal to the premises that the PoWRS model sets in order to get a good process and result. It is therefore our recommendation that the persons making the decision to apply the model must consider carefully whether they are willing to enter these premises. 
Since the target for the interventions is work and work processes, it is important to be aware of the work system (Carayon, 2009) which work processes are part of and which will be influenced by the changes and also will influence the concrete changes. It is therefore important that the project group is able to see the overall work system which in practice is being changed and not just the work processes. In the light of this discussion future research should therefore include the whole work-system in the research design in order to acknowledge the impact which the organizational context has on work-related interventions.

\section{Conclusion}

In this paper we have given special attention to the perceived enablers, barriers and outcomes of using a multi-level-participatory intervention model known as the PoWRS model with the purpose of increasing our understanding of which changes arise and especially what makes it work in SMEs.

Application of the PoWRS model SMEs appears to support a participatory multi-level process and results in work-related changes affecting both productivity and well-being.

However, in organizations where progress could be identified, one of the enablers was that everyone to some extend were engaged in reflections, decision making and implementation of the changes through all phases. The most important enabler was the in-house facilitators and project managers, who primarily drove the process. Besides, line managers and senior management walked-the-talk, and finally, evaluations and adjustments were made continuously and the progress was visualized.

In terms of barriers the results are more scattered across the companies. However, lack of time, daily operations and lack of commitment seem to be the primary constraints.

Our findings support the discussion regarding stress preventive interventions in SMEs and how companies can implement work-related changes by adapting an intervention model like PoWRS which gives a voice to employees in a multi-level participatory process.

\section{Acknowledgements}

Among all the contributors to this work, we want to give special thanks to the contributors of the four companies for their willingness to provide man hours to the research. We also want to thank Associate Professor Vibeke Andersen, Associate Professor Keld Pedersen, Senior Researcher Ole H. Sørensen and Mette Mogensen, PhD. for their valuable reflections and input during the research project. 
Andersen, V., \& Ipsen, C. (2010). POWRS - resultater fra udvikling af et koncept til organisatoriske forebyggelse af stress, udført i samarbejde med to videnvirksomheder. ( No. 12). Technical University of Denmark: DTU Management.

Armenakis, A. A., Bedian, A. B., \& Niebuhr, R. E. (1979). Planning for organizational intervention: The importance of existing socio-psychological situations in organiztional diagnosis. Group \& Organization Studies, 4(1), 59-70.

Brown, T. (2008). Design thinking. Harvard Business Review, (June), 84.

Buch, A., \& Andersen, V. (2008). Knowledge work and stress - beyond the job-strain model.

Buch, A., \& Andersen, V. (2009a). Knowledge work and stress - between strain and enthusiasm.

Buch, A., \& Andersen, V. (2009b). The meaning of work.

Buch, A., Andersen, V., \& Sథrensen, O. H. (2009). Videnarbejde og stress - mellem begejstring og belastning Jurist- og ¥konomforbundets Forlag.

Carayon, P. (2009). The balance theory and the work system model... twenty years later. International Journal of Human-Computer Interaction, 25(5), 313.

Cox, T., Karanika, M., Griffiths, A., \& Houdmont, J. (2007). Evaluating organizational-level work stress interventions: Beyond traditional methods. Work \& Stress, 21(4), 348-362.

Dahler-Larsen, P. (2001). From programme theory to constructivism. Evaluation, 7(3), 331. 
Dettinger, K. M., \& Smith, M. J. (2006). Human factors in organizational design and management. In Salvendy, \& Gavriel (Eds.), Handbook of human factors and ergonomics (3rd ed., pp. 513) John Wiley and Sons.

Editorial, S. S. (2011). Editorial: Occupational health and safety management systems: Issues and challenges. Safety Science, 49, 961-963.

European Agency for Safety and Health at Work. (2010). European survey of enterprises on new and emerging risks (ESENER). (). Bruxelles: European Agency for Safety and Health at Work.

Gray, D., Brown, S., \& Macanufo, J. (2010). Gamestorming A playbook for innovators, rulebreaker, and changemakers (1st ed.). California, USA: O'Reilly.

Greene, J. C. (1997). Participatory evaluation. In R. E. Stake, \& L. Mabry (Eds.), Advances in program evaluation (pp. 171-189). Greenwich, Connecticut: JAI Press Inc.

Hurrell, J. J., \& Murphy, L. R. (1996). Occupational stress intervention. American Journal of Industrial Medicine, 29(4), 338-341.

Ipsen, C. (2011). A participatory stress intervention process - the core of a self-help tool to succesful preventive changes. Work and Well-being in an Economic Context, Orlando, USA.

Ipsen, C., \& Andersen, V. (2013). A multi-level and participatory model for prevention of workrelated stress in knowledge work. In G. Bauer, \& G. Jenny (Eds.), Salutogenic organizations and change: The concepts behind organizational health intervention research [(Springer Publisher): Bauer G, Jenny G: Salutogenic organizations and change: The concepts behind organizational health intervention research.] (1st ed., pp. x-x) Springer. 
Ipsen, C., \& Andersen, V. (2011). "Forebyg stress - i en fcelles proces". København: DJØF's forlag.

Ipsen, C., \& Jensen, P. L. (2012). Organizational options for preventing work-related stress in knowledge work. International Journal of Industrial Ergonomics, 42(1), 325-334. doi:10.1016/j.ergon.2012.02.006

Ipsen, C., Jensen, P. L., \& Andersen, V. (2010). Prevention of work-related stress - A participatory approach. In P. Vink, \& J. Kantola (Eds.), Advances in occupational, social and organizational ergonomics (pp. 305-314). Florida, USA: CRC Press.

Ishikawa, K. (1968). Guide to quality control, productivity organization. Tokyo, Japan:

Jarret, T., Kimberly, H., \& Jianjun, Z. (2009). Teen perceptions of facilitator characteristics in a schoo-based smoking cessation program. Journal of School Health, 79(7)

Johnson, R. B., \& Onwuegbuzie, A. J. (2004). Mixed methods research: A research paradigm whose time has come. Educational Researcher, 33(7), 14; 3700093-26.

Johnson, R. B., Onwuegbuzie, A. J., \& Turner, L. A. (2007). Toward a definition of mixed methods research. Journal of Mixed Methods Research, 1(2), 112-133.

Jungk, R., \& Müllert, N. R. (1981). Zukunfts werkstätten. Hamburg: Hoffmann und Campe.

Kompier, M., \& Cooper, C. (1999). In Cooper C., Kompier M. (Eds.), Preventing stress, improving productivity. european case studies in the workplace. London: Routledge.

Kompier, M., Geurts, S. A. E., Gründemann, R. W. M., Vink, P., \& Smulders, P. G. W. (1998). Cases in stress prevention: The success of a participative and stepwise approach. Stress Medicine, 14, 155-168. 
Kompier, M., \& Kristensen, T. S. (2000). Organizational work stress interventions in a theoretical, methodological and practical context. In J. Dunham (Ed.), Stress in the workplace: Past, present and future (pp. 164-190)

Mellor, N., Mackay, C., Packham, C., Jones, R., Palferman, D., Webster, S., \& Kelly, P. (2011). "Managment standards" and work-related stress in great britain: Progress on their implementation. Safety Science, 49, 1040-1046.

Miles, M. B., \& Huberman, A. M. (1994). Qualitative data analysis an expanded sourcebook Sage Publications.

Murphy, L. R. (1988). Workplace interventions for stress reduction and prevention. In C. Cooper, \& R. Payne (Eds.), Causes, coping \& consequences of stress at work (pp. 301-339) John Wiley \& Sons Ltd.

Murphy, L. R., \& Sauter, S. L. (2003). The USA perspective: Current issues and trends in the management of work stress. Australian Psychologist, 38(2), 151-157.

Newell, S. (2002). Creating the healthy organization. well-being, diversity \& ethics at work. Cornwall: Thomson.

Nielsen, T. W., Grex, S., \& Jørgensen, A. (2010). På vej mod arbejdsmiljøvenlig ledelse af projekter? - hvordan IT-branchens ansatte opfatter arbejdsmiljøvenlig projektledelse. Aaalborg Universitet.

Nielsen, K., Fredslund, H., Christensen, K., \& Albertsen, K. (2006). Success or failure? interpreting and understanding the impact of interventions in four similar worksites. Work and Stress, 20(3) 
Nielsen, K., Raymond, R., Holten, A., \& González, E. R. (2010). Conducting organizational-level occupational health interventions: What works? Work \& Stress, 24(3), 234-259.

Nonaka, I., \& Teece, D. (2002). Managing industrial knowledge - creation, transfer and utilization

Randall, R., Cox, T., \& Griffiths, A. (2007). Participants' accounts of a stress management intervention. Human Relations, 60(8), 1181-1209.

Randall, R., Griffiths, A., \& Cox, T. (2005). Evaluating organizational stress-management interventions using adapted study designs. European Journal of Work and Organizational Psychology, 14(1), 23-41.

Rasmussen, L. B. (2008). The narrative aspect of scenario building. Cognition, communication and interaction: Transdisciplinary perspectives on interactive technology (pp. 174-194). London: Springer Verlag.

Rasmussen, L. B. (2011). In Rasmussen L. B. (Ed.), Facilitating change - using interactive methods in organizations, communities and networks (Book ed.). Polyteknisk Forlag:

Robson, C. (2002). Real world research : A resource for social scientists and practitionerresearchers (2nd ed.). Oxford: Blackwell Publishers.

Rosskam, E. (2009). Using participatory action research methodology to improve worker health. In P. L. Schnall, M. Dobson \& E. Rosskam (Eds.), Unhealthy work: Causes, consequences, cures (1st ed., pp. 211-228). Amityville, New York: Baywood Publishing Company.

Saksvik, P. Ø., Nytrø, K., Dahl-Jørgensen, C., \& Mikkelsen, A. (2002). A process evaluation of individual and organizational stress and health interventions. Work \& Stress, 16, 37-57. 
Simon, H. A. (1981). The sciences of the artificial (2nd ed.). Cambridge, Mass.: MIT Press.

Singer, J. A., Neale, M. S., Schwartz, G. E., \& Schwartz.J. (1986). Conflicting perspectives on stress reduction in occupational settings: A systems approach to their resolution. In M. F. Cataldo, \& T. J. Coates (Eds.), Health and industry. A behavioral medicine perspective (pp. 162-193) John Wiley \& Sons.

Smith, M. J., \& Sainfort, P. (1989). A balance theory of job design for stress reduction. International Journal of Industrial Ergonomics, 4(1), 67-79.

Sørensen, O. H. (2010). Fiskebensmetoden - hvilke ben er der i den? Tidskrift for Arbejdslivsk, 2

Sørensen, O. H., \& Holman, D. (2010). Job-reredesign in knowledge work. In P. Vink, \& J. Kantola (Eds.), Advances in occupation, social, and organizational ergonomics (pp. 111-120) CRC Press, Taylor \& Francis Group.

Womack, J. P., Jones, D. T., \& Roos, D. (2007). The machine that changed the world : The story of lean production, toyota's secret weapon in the global car wars that is revolutionizing world industry (New ed.). London: Simon \& Schuster.

Yin, R. K. (1989). Case study research - design and methods Sage Publications, Inc. 